\title{
DeterminanTS OF CHRONIC DISEASE ACCEPTANCE
}

\author{
Iwona Oskędra' ${ }^{1 A, C, D, E, F}$, Natalia Synowiec ${ }^{2 A, B, C}$, Katarzyna Wojtas ${ }^{30, E, F}$
}

\author{
'Department of Nursing Management and Epidemiological Nursing, Institute of Nursing \\ and Midwifery, Faculty of Health Sciences, Jagiellonian University Medical College, Cracow, \\ Poland \\ ${ }^{2}$ Department of Cardiovascular Diseases with Cardiac Intensive Care Unit, John Paul II Specialist \\ Hospital, Cracow, Poland \\ ${ }^{3}$ Department of Clinical Nursing, Institute of Nursing and Midwifery, Faculty of Health Sciences, \\ Jagiellonian University Medical College, Cracow, Poland
}

Authors' contribution:

A. Study design/planning • B. Data collection/entry $\bullet$ C. Data analysis/statistics $\bullet$ D. Data interpretation $\bullet$ E. Preparation of manuscript $\bullet F$. Literature analysis/search $\bullet$ G. Funds collection

\author{
Address for correspondence: \\ Dr Katarzyna Wojtas \\ Department of Clinical Nursing \\ Institute of Nursing and Midwifery \\ Faculty of Health Sciences \\ Jagiellonian University Medical College \\ Cracow, Poland \\ e-mail: katarzyna.wojtas@uj.edu.pl
}

SUBMITTED: 21.08 .2021

ACCEPTED: 29.09.2021

DOI: https://doi.org/10.5114/ppiel.2021.113786

\begin{abstract}
Introduction: The process of chronic disease acceptance is long-lasting and varies depending on the type of disease, and it is conditioned by factors that have their cause both in the course of the disease and in the socio-demographic situation.

Aim of the study: To identify the determinants of chronic disease acceptance.

Material and methods: A diagnostic survey was conducted through the Helpful Hand Foundation and in the John Paul II Specialist Hospital in Cracow at the Department of Cardiovascular Diseases with Cardiac Intensive Care Unit, among 150 patients aged 32-60 years, with diagnosed multiple sclerosis, heart failure, and chronic obstructive pulmonary disease. The study used standardized tools: the Beck Depression Inventory, Acceptance of Illness Scale (AIS), and the author's survey questionnaire. The IBM SPSS 26.0 package was used for statistical analysis, and a significance level of $p<0.05$ was assumed for all statistical calculations.

Results: The average degree of the acceptance of illness according to the AIS scale among all 150 respondents was 27.31 points, which indicates an average degree of acceptance of illness by the respondents. Higher scores in the AIS scale were obtained by subjects who were in remission $(p=0.007)$ and who lived in small towns $(p=0.044)$. Conclusions: The results confirm a relationship between the acceptance level of disease and selected elements of the course of disease and demographic variables. Patients' acceptance of the disease should be taken into account in therapeutic interventions due to the possibility of undertaking measures aimed at eliminating some of the unfavourable factors conditioning the acceptance of disease.
\end{abstract}

Key words: surgical site infections, surgical site infection prevention, orthopaedics, perioperative care.

\section{INTRODUCTION}

Chronic disease is characterized by a long-term course, and the presence of dysfunction or disability, which requires targeted observation of the condition as well as care and rehabilitation interventions for patients. Chronic diseases include multiple sclerosis, and chronic respiratory and cardiovascular diseases, among others [1]. Specialist interventions are aimed at reducing the risk of life-threatening conditions, reducing the symptoms of the disease [2], and facilitating adaptation to the changed life situation. The full understanding of the patient's situation is possible with its wider, also non-medical assessment. The fact of different adaptation activities in the course of a particular disease should be emphasized [3]. The condition of adaptation to the disease is its acceptance, which is influenced by social support [4], especially from the closest family and therapeutic team supporting the dignity of each patient [5], as well as knowledge about the disease, its course and prognosis, the patient's mental state, general health status, and socio-demographic factors [4]. Acceptance of changes in functioning as a result of illness is sometimes challenging [3], and how the patient perceives the disease is important in the coping process [6]. Acceptance is considered an indicator of overall adaptation to chronic disease [7] and contributes to maintaining independence [8]. Assessment of the degree of acceptance of one's own illness is extremely important both in medical and nonmedical care. This degree of acceptance determines the patients' ability to function and the evaluation of their quality of life with the disease. The higher it is, the lower the intensity of negative emotions felt by the patient [9]. The assessment of the degree of acceptance of illness can be carried out by the physician or nurse as part of their cooperation in the therapeutic team. Thus, by maintaining authenticity with the patient, they make necessary interventions and show empathy and acceptance towards the patient. In this way, they can provide patients with sources of support 
in dealing with their illness, and change their self-perception and their perception of the illness itself.

\section{AIM OF THE STUDY}

The aim of this study was to identify the determinants of chronic disease acceptance, taking heart failure, chronic obstructive pulmonary disease, and multiple sclerosis as examples.

\section{MATERIAL AND METHODS}

The study was conducted from January to May 2021, through the Helpful Hand Foundation and at the John Paul II Specialist Hospital in Cracow, Poland, at the Department of Cardiovascular Diseases with Cardiac Intensive Care Unit. The inclusion criteria were as follows: diagnosis of multiple sclerosis (MS), heart failure (HF), or chronic obstructive pulmonary disease (COPD), in patients aged 30-60 years, and a minimum of 2 years of disease duration. The patients gave verbal, informed, and voluntary consent to participate in the study, being informed about the anonymity and purpose of this study, the way of filling out the research tools, the planned use of data, and the possibility of resignation from participation in the study at any stage without giving a reason.

The study covered a total of 150 patients, who were divided into 3 equal-sized groups of 50 patients each, depending on the diagnosis. Women constituted $56.0 \%$ of the study subjects, and men $44.0 \%$. The mean age was 51 years, with the highest number of patients between 51 and 60 years of age $-65.3 \%$. The youngest person in the MS group was 35 years old and the oldest 60 years old, in the heart failure group the youngest person was 32 years old and the oldest was 60 years old, while in the COPD group the age range was 47-60 years old. Among the respondents, the largest number of patients had higher education $-47.3 \%$, lived in an urban area $-81.3 \%$, were married $-57.3 \%$, and were parents $-68.7 \%$.

Table 1. Acceptance level of disease by the subjects

\begin{tabular}{|c|c|c|c|c|c|c|}
\hline \multirow{2}{*}{$\begin{array}{l}\text { Chronic } \\
\text { disease }\end{array}$} & \multicolumn{6}{|c|}{ Acceptance of Illness Scale } \\
\hline & $N$ & Mean & SD & Me & Min & Max \\
\hline $\mathrm{HF}$ & 50 & 27.76 & 4.003 & 28.00 & 16 & 35 \\
\hline COPD & 50 & 28.56 & 3.609 & 30.00 & 18 & 34 \\
\hline MS & 50 & 25.60 & 7.688 & 25.50 & 8 & 39 \\
\hline Total & 150 & 27.31 & 5.528 & 28.00 & 8 & 39 \\
\hline $\begin{array}{l}\text { H Kruskal- } \\
\text { Wallis }\end{array}$ & \multicolumn{6}{|c|}{5.176} \\
\hline$p$ & \multicolumn{6}{|c|}{0.075} \\
\hline
\end{tabular}

Patients suffered from the disease for 3 to more than 20 years (average 9 years). In the majority of respondents $-70 \%$, the disease was in remission, in $77.3 \%$ of people there were no complications of chronic disease, and $60.7 \%$ of patients knew the prognosis of their disease. More than half of the respondents $-53.3 \%$, rated their knowledge of disease as "good" with the comment: "but I don't know everything about it". Respondents had comorbidities: $51.3 \%$ mentioned cardiovascular diseases, $27.3 \%$ thyroid and parathyroid diseases, and $30.7 \%$ indicated "other" problems, i.e. vision and hearing disorders, skin lesions, endocrinopathy, migraines, spondylosis, anaemia, or cancer.

The research method was a diagnostic survey, and the technique was a questionnaire. The research tools included: the author's survey questionnaire containing questions about sociodemographic data, family situation, health, knowledge on the disease, and received support; and the Beck Depression Inventory assessing the severity of depressive disorders, consisting of 21 questions with answers scored on a scale from 0-3. The result obtained was compared with the test scale [10]. The Acceptance of Illness Scale (AIS) by Felton, Revenson, Hinrichsen, in Juczyński's adaptation, consisting of 8 statements, measuring the acceptance level of disease, based on the assessment of responses on a scale from 1 to 5 points. A low score is interpreted as a lack of disease acceptance, while a high score as its acceptance. The scale has no standards, and the obtained score is compared with the results of studies by other authors [11].

Analyses were conducted in the IBM SPSS 26.0 package with the Exact Tests module. The statistical methods used were $\chi^{2}$ test, Mann-Whitney $U$ test, Kruskal-Wallis test, and coefficients based on Phi and $\mathrm{V}$ Kramer tests to determine the strength of association.

All tests were 2-sided, and the statistical significance was adopted as $p<0.05$.

\section{RESULTS}

\section{Acceptance level of disease by the subjects}

The mean acceptance level of disease was 27.31; $\mathrm{SD}=5.53$. No statistically significant relationship between type of disease and acceptance level of disease was confirmed (Table 1).

\section{Analysis of the relationship between the degree of acceptance of illness and selected variables}

The relationship between the acceptance level of disease and the severity of depressive disorders, variables characterizing chronic disease, and sociodemographic variables were statistically analysed. 


\section{Acceptance level of disease and severity} of depressive disorders

The greater the severity of depressive disorders among the subjects, the lower the acceptance level of disease (Table 2).

\section{Acceptance level of disease vs. duration of disease}

The duration of the disease was not related to the acceptance level of disease (Table 3).

Subjects in remission obtained higher scores on the AIS scale compared to subjects with exacerbation of symptoms ( $p=0.007$ ). Subjects who did not report symptoms of disease had a lower acceptance level compared to individuals confirming their presence $(p=0.040)$.

The subjects' level of knowledge about the disease, presence of comorbidities, and knowledge of prognosis were not associated with acceptance of illness $(p>0.05)$.

\section{Acceptance level of disease and sociodemographic variables}

The acceptance level of chronic disease was not statistically significantly differentiated by the subjects' age $(p=0.216)$, gender $(p=0.554)$, marital status ( $p=0.689)$, education $(p=0.690)$, or support from a loved one $(p=0.068)$. People living in small towns had higher levels of disease acceptance compared to other respondents $(p=0.044)$.

\section{DISCUSSION}

Chronic diseases are diagnosed in middle adulthood, i.e. between the ages of 35 and 65 years [3], and although they are usually attributed to older people, some are diagnosed at a young age [2]. The study also confirms this; the youngest person participating in the study was 32 and the oldest was 60 years old.

The patients' acceptance level of disease varied in the study, with a mean score of 27.31, indicating a medium acceptance level, and the diagnosis was not significantly related to disease acceptance. For comparison, in Andruszkiewicz's study, the patients also presented an average acceptance level of disease $M=27.63$ [5]. The mean scores of the AIS scale in the study among patients with multiple sclerosis, chronic obstructive pulmonary disease, and heart failure were 25.60 vs. 28.56 vs. 27.76, respectively. The acceptance level of disease in the studies of other authors also varied. The mean obtained by patients with COPD in Kupcewicz's study was 19.00 [12], in Majda's study it was 20.6 [13], and the median in Uchmanowicz's results was 24.0 [4]. The studies conducted by Gościcka showed that the acceptance among patients was at a medium level [14]. For com-
Table 2. Severity of depressive disorders and acceptance level of disease

\begin{tabular}{lcc}
\hline Chronic disease & $\begin{array}{c}\text { Acceptance } \\
\text { of Illness Scale }\end{array}$ & $\begin{array}{c}\text { Beck Depression } \\
\text { Inventory }\end{array}$ \\
\hline$p$ & 0.000 & 0.000 \\
\hline Correlation coefficient & $-0.520^{\star *}$ & 1.000 \\
\hline
\end{tabular}

** Correlation significant at the 0.01 level (bilateral), $p$-significance level $p<0.05$

Table 3. Duration of disease and acceptance level of chronic disease

\begin{tabular}{lcccccc}
\hline \multirow{2}{*}{$\begin{array}{l}\text { Duration } \\
\text { of illness } \\
\text { (years) }\end{array}$} & $\boldsymbol{N}$ & Mean & SD & Me & Min & Max \\
\cline { 2 - 7 } & 63 & 28.65 & 4.017 & 30.00 & 17 & 36 \\
\hline to 5 & 51 & 27.27 & 4.468 & 28.00 & 14 & 35 \\
\hline 6 to 10 & 24 & 25.71 & 7.838 & 27.00 & 9 & 39 \\
\hline 11 to 20 & 12 & 23.58 & 8.533 & 24.50 & 8 & 37 \\
\hline Over 20 & 150 & 27.31 & 5.528 & 28.00 & 8 & 39 \\
\hline Total & \multicolumn{7}{c}{7.644} \\
\hline H Kruskal- \\
Wallis
\end{tabular}

parison, in the study by Robaszkiewicz-Bouakaz et al. the mean level of disease acceptance in the group of MS patients was 29.82 [15], and in the study by Rosińczuk et al. the acceptance index was 24.83 [16]. Similar values were obtained by Dymecka et al., i.e. 24.20 [17]; in the study of Kottuniuk et al. the mean level of disease acceptance was 28.3 [18]. Piasecka et al. obtained a value of 27.15 [19], and for PejasGrzybek et al. it was 25.08 [20]. The study conducted by Furmańska et al. confirmed the disease acceptance $(M=30.73)$ by $M S$ patients [21]. In the group of patients with heart failure, Uchmanowicz et al. obtained a score of 20.06 [22].

Due to the presence of 3 groups of patients with different diagnoses in the study, the analysis of relationships between the acceptance level of chronic disease and selected sociodemographic variables and those related to the course of disease will be presented according to the scheme: our results and then the results of other authors concerning specific diseases.

The study results showed that the acceptance level of disease was related to the severity of depressive disorders - the higher the severity of these disorders in the subjects, the lower the acceptance level of disease. Moreover, a significant statistical relationship between a higher acceptance level and remission period and living in a small urban area was confirmed. On the other hand, lower values in the AIS scale were obtained by the subjects who did not report symptoms of disease, compared to individuals 
who confirmed their presence. The acceptance level of chronic disease was not statistically significantly differentiated according to the age of respondents, gender, marital status, education level, and support from loved ones. The level of knowledge on the disease, coexisting diseases, and prognosis were not associated with disease acceptance.

Andruszkiewicz's study among chronically ill patients showed that gender did not differentiate the acceptance level, whereas subjects with a low level of disease acceptance reported significantly more complaints about their somatic condition, anxiety, and depression [5].

The results of study conducted by Gościcka among patients with COPD confirmed that the disease acceptance level was not significantly related to gender, age, education, or marital status. Persons living in the city obtained higher values in the AIS scale, whereas coexisting diseases decreased the disease acceptance level [14].

The study by Majda et al. showed that women and city residents had significantly higher AIS scores. Moreover, the higher the acceptance level, the fewer the exacerbations of COPD per year [13]. According to the results obtained by Jankowska-Polańska et al. among patients with such a diagnosis, the higher the education and the shorter the duration of disease, the higher the acceptance level, whereas the older the age, the more severe the disease, and the greater the severity of symptoms and hospitalizations due to exacerbations, the lower the acceptance level. Gender did not differentiate the acceptance level of disease among patients [23]. The acceptance level among patients with COPD in the study conducted by Kupcewicz et al. was significantly higher among women, employed individuals, and those less frequently hospitalized and it increased with the subjects' age. However, the duration of illness, comorbidities, education, and place of residence were not related to the disease acceptance level [12]. In the study undertaken by Marx et al., patients with COPD had difficulty in accepting the situation with regard to the disease, having a vague sense of it [24]. Difficulties in accepting the disease and the resulting limitations were also present in patients with COPD in a study conducted by Pierobon et al., and additionally, depressive symptoms were confirmed among these patients [25]. Uchmanowicz et al. confirmed the presence of negative emotions and depression among the patients in their study, and a statistically significant correlation was found between the acceptance of disease and the severity of depressive symptoms. Moreover, no coexisting diseases had a positive effect on the acceptance of disease [22]. The analysis of available studies shows that depression is the most frequently diagnosed comorbidity in the course of COPD, and the risk of its development is several times higher than in patients without COPD [26]. Mood assessment and implementation of antidepressant treatment are extremely important and may be related to improved disease acceptance [22].

The study undertaken by Uchmanowicz et al. in subjects with heart failure showed that comorbidities were not related to disease acceptance, nor was the place of residence of the subjects. However, individuals who were inactive had a lower acceptance level. Respondents who evaluated positively the support from loved ones obtained a significantly higher acceptance level of disease [4]. The study results by Kulig et al. showed that there were no statistically significant differences between the gender of the subjects with heart failure and acceptance of disease [27], while the acceptance level decreased with the subjects' age. Disease acceptance among patients with heart failure was also studied by Obiegło et al. Individuals with lower levels of disease acceptance were more likely to show negative emotions [7]. Similarly, in the study conducted by Dekker et al., depressive symptoms were confirmed in patients with heart failure, but based on the patients' description, these symptoms did not have a somatic dimension [28].

The study by Robaszkiewicz-Bouakaz et al. showed that the highest acceptance of disease was found among MS patients with higher education, studying and professionally active, and diagnosed at a young age. However, there were no statistically significant correlations between acceptance of disease and gender, place of residence, and marital status. The analysis also showed no statistically significant relationships between support and acceptance of disease [15].

In a study conducted by Król et al. among MS patients, sociodemographic variables had no significant relationship with disease acceptance, while a negative relationship was found between duration of illness and acceptance [29]. Studies in a group of people with MS confirmed the presence of varying severity of depressive disorders [30].

The authors' study did not confirm a significant relationship between acceptance of chronic disease and the knowledge of respondents regarding the disease. However, it is worth noting that patients assessed the knowledge as good but considered it incomplete. In comparison, a study by Gutknecht et al. showed that patients with COPD had difficulty reading the abbreviation "COPD" but had knowledge of the nature of this disease [31].

Patient education is an important part of professional care and is undertaken by physicians, as demonstrated by Hernandez, but this is not always acknowledged by patients [32]. The importance of education and relevance of information provided by physicians, nurses, and physiotherapists on the disease was also recognized by patients with COPD in a study conducted by Sigurgeirsdottir et al. Some pa- 
tients pointed out that it was undertaken too late, and the Internet did not prove to be a good source of knowledge [33].

The presented research did not focus on MS treatment methods; nevertheless, this aspect is important because treatment methods shaping the course of disease may also influence its acceptance.

Treatment of a chronic disease requires adherence to medical recommendations, active cooperation, and acceptance of disease, and the implemented treatment methods may be associated with experiencing equal emotions. The results of a study conducted by Kottuniuk showed that patients with MS experienced both anxiety, depression, irritation, and anger. The importance of disease acceptance is extremely important in the course of treatment, and therefore its assessment, in the opinion of researchers, should be a constant element during the patient's follow-up visit [18], similarly to the assessment of experienced emotions. The progress of medicine allows the implementation of different methods or the improvement of those already existing, providing optimal comfort and effectiveness of treatment [34], but it is the patient who ultimately decides to undertake treatment and chooses from the proposed methods the one that in his/her opinion seems to be the best.

Chronic disease is of interest to many specialists, thus indicating the need for an interdisciplinary approach in health care provision [3]. In its image, it is dynamic due to periods of remission and exacerbation, which may be related to changes in the individual's self-perception [35], life situation, and experiencing different emotions. In addition, it forces reflection on how to maintain health and independence as well as systematicity and/or modification of treatment. It seems that the therapeutic team can contribute to the process of disease acceptance by the patient through the attitude presented, in which an empathic understanding of the situation resulting from the disease limitations prevails, as well as by undertaking educational activities towards the family on the disease, thus increasing the chance of their involvement in providing support in the progressive process of disease developmentlt is worth noting that the higher the acceptance level of disease, the more constructive and committed the patient's attitude in fighting the disease contributing to the improvement of quality of life [14].

The acceptance of chronic disease addressed in our study does not constitute a new issue. However, due to the heterogeneous group of patients with chronic diseases, the results obtained allow us to broaden the area of knowledge in this regard. Despite numerous studies related to the acceptance of illness, conducted by many authors, this subject still seems to be important and relevant. When undertaking this area of research, the authors had in mind the progress in medicine and innovative treatment methods for chronic diseases. Very often, this progress can prolong the life of chronically ill patients, but it does not always improve their quality of life or lead to a high level of acceptance of illness.

The patient's degree of acceptance of their illness should be taken into account by professionals who provide health care services, thus reflecting a holistic approach to care. Emphasizing the importance of the patients' own judgment as they struggle with a chronic disease prevents generalizing opinions on disease acceptance and perceiving it through the prism of therapeutic team's own feelings. The research results presented here have the potential to sensitize the presence of this phenomenon, which can actually be related to the patient's functioning and quality of life.

\section{CONCLUSIONS}

A higher degree of the acceptance of illness was reported among subjects in remission and among urban residents, while a lower degree of the acceptance of illness was related to the severity of depressive disorders and not reporting/experiencing symptoms of illness.

There is a need for further research to assess the degree of acceptance of chronic diseases and the search for factors determining it.

\section{Disclosure}

The authors declare no conflict of interest.

\section{References}

1. Markocka-Maczka K, Grabowski K, Taboła R. Choroby przewlekłe - problem XXI wieku. In: Dybińska E, Zboina B (Eds.). Dobrostan a edukacja. Wyd. NeuroCentrum, Lublin 2016; 177-186.

2. Dołęga Z, Płachetka J. Rozpoznanie przewlekłej choroby somatycznej jako źródło kryzysu w okresie wczesnej dorosłości. In: Popiołek K, Bańka A, Zalewska-Łunkiewicz K (Eds.). Kryzysy osobiste i systemowe. Stowarzyszenie Psychologia i Architektura - Uniwersytet SWPS, Poznań - Katowice 2017; 134-142.

3. Ziarko M. Zmaganie się ze stresem choroby przewlekłej. Wydawnictwo Naukowe Wydziału Nauk Społecznych UAM, Poznań 2014.

4. Uchmanowicz I, Pieniacka M, Kuśnierz M, et al. Problem akceptacji choroby a jakość życia pacjentów z niewydolnością serca. Probl Pielęg 2015; 23: 69-74.

5. Andruszkiewicz A, Nowik M, Kubica A, et al. Stan zdrowia a akceptacja choroby $w$ grupie pacjentów przewlekle chorych. Przeds Zarz 2013; t. 14, z. 10, cz. 2 - Wybrane problemy organizacji i zarządzania w pielęgniarstwie. Pielęgniarstwo bez granic; 233-242.

6. Miniszewska J, Adamska M. Przekonania na temat zdrowia i choroby a akceptacja ograniczeń wynikających z przewlekłej choroby somatycznej na przykładzie osób z łuszczycą. Psychiatr Psychol Klin 2014; 14: 202-212. 
7. Obiegło M, Uchmanowicz I, Wleklik M, et al. The effect of acceptance of illness on the quality of life in patients with chronic heart failure. Eur J Cardiovasc Nurs 2016; 15: 241-247.

8. Kuczyńska A, Sienkiewicz Z. Wpływ przewlekłej obturacyjnej choroby płuc na funkcjonowanie pacjenta w rodzinie. Geriatria 2019; 13: 83-89.

9. Mazurek J, Lubriecki J. Skala Akceptacji Choroby i jej znaczenie w praktyce klinicznej. Pol Merkuriusz Lek 2014; XXXVI: 106-108.

10. Parnowski T, Jernajczyk W. Inwentarz Depresji Becka w ocenie osób zdrowych i chorych na choroby afektywne (ocena pilotażowa). Psychiatr Pol 1977; 11: 417-425.

11. Juczyński Z. Narzędzia pomiaru w promocji i psychologii zdrowia. Wyd. II. Pracownia Testów Psychologicznych Polskiego Towarzystwa Psychologicznego, Warszawa 2012; 162-166.

12. Kupcewicz E, Abramowicz A. Wpływ wybranych czynników socjodemograficznych na stopień akceptacji choroby i poziom satysfakcji z życia u pacjentów leczonych z powodu przewlekłej obturacyjnej choroby płuc. Hygeia Public Health 2015; 50: 142-148.

13. Majda A, Józefowska H. Zasoby osobiste pacjentów z przewlekłą obturacyjną chorobą płuc. Probl Pielęg 2009; 17: 283-293.

14. Gościcka M. Ocena akceptacji choroby przewlektej na przykładzie pacjentów z przewlekłą obturacyjną chorobą płuc. Innow Pielęgniarstwie Nauk Zdr 2016; 2: 63-78.

15. Robaszkiewicz-Bouakaz R, Kołaczyk M, Owsianowska J, et al. Stopień akceptacji choroby pacjentów ze stwardnieniem rozsianym. Pielęg Opiece Długoterminowej 2020; 4: 25-33.

16. Rosińczuk J, Rychła K, Bronowicka J, et al. The impact of illness acceptance on quality of life of patients with multiple sclerosis - preliminary study. Pieleg Neur Neurochir 2017; 6: 157-162.

17. Dymecka J, Bidzan M. Biomedical variables and adaptation to disease and health-related quality of life in Polish patients with MS. Int J Environ Res Public Health 2018; 15: 2678.

18. Kołtuniuk A, Rosińczuk J. Poziomy depresji, lęku, akceptacji choroby i stosowania leków u pacjentów ze stwardnieniem rozsianym - badanie opisowe i korelacyjne. Int J Med Sci 2021; 18: 216-225.

19. Piasecka MA. Cechy demograficzne chorych na stwardnienie rozsiane a poziom akceptacji choroby wg skali AIS. Pielęg Opiece Długoterminowej 2017; 4: 4-16.

20. Pejas-Grzybek L, Skorupska-Król A. The degree of illness acceptance among patients with multiple sclerosis. Pieleg Neur Neurochir 2015; 4: 19-23.

21. Furmańska J, Koziarska D, Szcześniak M, et al. Sexual satisfaction, self-esteem and acceptance of illness among relapse-remitting multiple sclerosis patients. Adv Psychiatry Neurol 2017; 26: 236-245.

22. Uchmanowicz I, Jankowska-Polańska B, Motowidło U, et al. Assessment of illness acceptance by patients with COPD and the prevalence of depression and anxiety in COPD. Int J Chron Obstruct Pulmon Dis 2016; 11: 963-970.

23. Jankowska-Polańska B, Kasprzyk M, Chudiak A, et al. Relation between illness acceptance and quality of life in patients with chronic obstructive pulmonary disease (COPD). Pneumonol Alergol Pol 2016; 84: 3-10.

24. Marx G, Nasse M, Stanze $H$, et al. Meaning of living with severe chronic obstructive lung disease: a qualitative study. BMJ Open 2016; 6: e011555.

25. Pierobon A, Sini Bottelli E, Ranzini L, et al. COPD patients' self-reported adherence, psychosocial factors and mild cognitive impairment in pulmonary rehabilitation. Int J Chron Obstruct Pulmon Dis 2017; 12: 2059-2067.
26. Pollok J, van Agteren JE, Esterman AJ, et al. Psychological therapies for the treatment of depression in chronic obstructive pulmonary disease. Cochrane Database Syst Rev 2019; 3: CD012347.

27. Kulig K, Filanowicz M. Correlation analysis between disease acceptance and satisfaction with life among patients hospitalized due to heart failure in cardiology departments. Pol J Appl Sci 2018; 4: 18-23.

28. Dekker RL. Patient perspectives about depressive symptoms in heart failure: a review of the qualitative literature. J Cardiovasc Nurs 2014; 29: E9-15.

29. Król J, Szcześniak M, Koziarska D, et al. Akceptacja choroby i postrzeganie czasu u osób leczonych immunomodulacyjnie z rzutowo-remisyjną postacią stwardnienia rozsianego (RR-SM). Psychiatr Pol 2015; 49: 911-920.

30. Halicka D, Tarasiuk J, Szczepański M, et al. Fatique syndrome, depression and the quality of life in patients with multiple sclerosis. Pieleg Neur Neurochir 2017; 6: 81-87.

31. Gutknecht P, Trzeciak BG, Siebert J. Wiedza pacjentów na temat przewlekłej obturacyjnej choroby płuc. Fam Med Prim Care Rev 2014; 16: 99-100.

32. Hernandez P, Balter MS, Bourbeau J, et al. Canadian practice assessment in chronic obstructive pulmonary disease: respiratory specialist physician perception versus patient reality. Can Respir J 2013; 20: 97-105.

33. Sigurgeirsdottir J, Halldorsdottir S, Arnardottir RH, et al. COPD patients' experiences, self-reported needs, and needsdriven strategies to cope with self-management. Int J Chron Obstruct Pulmon Dis 2019; 14: 1033-1043.

34. Visser LA, De Mul M, Redekop WK. Innovative medical technology and the treatment decision-making process in multiple sclerosis: a focus group study to examine patient perspectives. Patient Prefer Adherence 2021; 15: 927-937.

35. Neustein J, Pawik M, Rymaszewska J. Stres i obraz siebie wśród osób chorujących na stwardnienie rozsiane oraz wybrane pozytywne aspekty zmagania się z chorobą. Aktual Neurol 2018; 18: 34-39. 